\title{
The Effect of Soursop (Announa Muricata L.) Leaves Powder on Diameter of Muscle Fiber, Lipid Cell, Body Weight Gain and Carcass Percentage of Tegal Duck
}

\author{
Elly Tugiyanti, Nur Mawarti, Rosidi, Ibnu Harisulistyawan \\ Faculty of Animal Science, Jenderal Soedirman University, Purwokerto 53123 \\ *Corresponding author email: tugiyanti.elly@gmail.com
}

\begin{abstract}
The present study investigated the supplementation of soursop leaves powder (Annona muricata L.) on body weight gain and carcass percentage of male Tegal duck. The study was conducted from 29 November 2015 to 3 January 2016 in duck cage in Sokaraja Kulon, Purwokerto. One hundred male Tegal duck were fed basal feed consisted of $30 \%$ corn, $7 \%$ soy bean meal, $6.1 \%$ vegetable oil, $17 \%$ poultry meat meal, $38.2 \%$ ricebran, $0.1 \%$ L-lysin $\mathrm{HCL}, 0.3 \% \mathrm{DL}$-methionin, $0.2 \%$ topmix, $0.1 \% \mathrm{NaCl}$, and $1 \% \mathrm{CaCO}_{3}$. The experimental research used completely randomized design involving basal feed plus $0,5,10$, and $15 \%$ supplemental soursop leaves meal, each with 5 replicates. The diameter of muscle fiber, lipid cell, body weight gain and carcass percentage were measured. The obtained data were subject to analysis of variance followed by orthogonal polynomial test. Result showed that treatments non significantly $(P>0.05)$ affected the diameter of chest muscle fiber, carcass percentage and carcass but significantly affected $(P<0.05)$ body weight gain with equation $Y=427.74-67.10 X+2.27 X^{2}$. Conclusively, supplemental soursop leaves meal (Annona muricata L.) in feed cannot increase the muscle fiber diameter of intermuscular lipid cell, carcass percentage and carcass components. Excessive supplement even lowers body weight gain of male Tegal duck.

Key words: soursop leaves, flavonoid, carcass, muscle fiber, male Tegal duck
\end{abstract}

Abstrak. Penelitian ini bertujuan untuk mengetahui pengaruh suplementasi tepung daun sirsak (Annona muricata L.) dalam pakan terhadap pertambahan bobot badan dan persentase karkas pada itik Tegal jantan. Penelitian telah dilaksanakan pada 29 November 2015 - 3 Januari 2016 di kandang itik Sokaraja Kulon, Purwokerto. Materi penelitian menggunakan 100 ekor itik tegal jantan, pakan basal yang diberikan terdiri atas jagung $30 \%$, tepung kedelai $7 \%$, minyak sayur $6,1 \%$, tepung daging $17 \%$, dedak $38,2 \%$, L-lysin $\mathrm{HCL} 0,1 \%$, DLmethionin 0,3\%, topmix 0,2\%, $\mathrm{NaCl} 0,1 \%$, dan $\mathrm{CaCO}_{3} 1 \%$. Metode penelian yang digunakan metode eksperimen dengan rancangan Rancangan Acak Lengkap. Perlakuan terdiri atas : pakan basal ditambah 0\% tepung daun sirsak, pakan basal ditambah 5\% tepung daun sirsak, pakan basal ditambah $10 \%$ tepung daun sirsak, pakan basal ditambah $15 \%$ tepung daun sirsak. Tiap perlakuan diulang 5 kali dan variabel yang diamati adalah diameter otot, sel lemak, pertambahan bobot badan dan carcass percentage. Data yang diperoleh dianalisis menggunakan analisis ragam dan dilanjutkan dengan uji orthogonal polinomial. Hasil analisis ragam menunjukkan bahwa perlakuan berpengaruh tidak nyata $(P>0,05)$ terhadap diameter of breast muscle fiber, tebal sel lemak, carcass percentage dan bagian-bagian karkas, akan tetapi berpengaruh nyata $(P<0,05)$ terhadap pertambahan bobot badan dengan persamaan garis $Y=427,74-67,10 X+2,27 X^{2}$. Kesimpulan penelitian ini adalah penambahan tepung daun sirsak (Annona muricata L.) dalam pakan belum mampu meningkatkan diameter otot, sel lemak intramuskuler dan persentase karkas dan bagian-bagiannya, bahkan jika pemberiannya berlebihan dapat menurunkan pertambahan bobot badan itik Tegal jantan.

Kata kunci: Daun Sirsak, Flavonoid, Karkas, otot, itik Tegal jantan

\section{Introduction}

Tegal ducks are commonly farmed in Tegal regency and extended to West Java, Papua, Aceh, Lampung and South Sulawesi (Prasetyo et al., 2004; Susanti and Prasetyo, 2007). Tegal duck is not only known for egg production, but also a potential producer of poultry meat. Recently, duck meat is craved by rural to urban society because of the particular taste and nutrition value of duck meat that is comparable to that of chicken, with $18.6-20.8$ vs. $21.4-22.6$ protein and $2.7-8.2$ vs. $4.8 \%$ fat content, respectively (Jun et al., 1996; Srigandono, 1997; Kim et al., 2006).

Feed is one of the contributing factors of ducks' growth and body index. Quality and 
quantity of meat significantly determine performance, maintenance and various biological processes (Sudiyono and Purwatri, 2007). Rehfeldt et al. (2004) stated that lack nutrients or limited feed given to the hatched poultry leads to small diameter of muscle fiber and few numbers per fasciculus. Choi and Kim (2008) also reported that sufficient supply of energy and protein for protein synthesis in muscle cell is expressed in the size of muscle fiber.

The occurrence of different diseases in poultry frequently lowers duck's productivity such as growth and carcass percentage. Antibiotic has long been used to prevent disease and increase performance of cattle but has negative effect on bacteria resistance in cattle and harms human health; therefore, the utilization of antibiotics to cattle feed is limited. This issue increases the use of natural ingredients as functional phytogenic feed (essential oil, flavonoid, saponin and tannin) to improve cattle nutrition, performance and health and the quality of cattle feed.

Plant as alternative medicine for traditional medication becomes more popular as synthetic medicine gets more expensive (Chikmawati and Miftahudin, 2011). Soursop leaves is one of natural ingredients that contains many active substance to prevent disease and improve productivity of ducks. Soursop leaves contain flavonoid, tannin, phytosterol, oxalate calcium, alkaloid, acetogenins, phytosterols and steroid (Suranto, 2011). Flavonoid is antioxidant that protects cell structure, improves efficacy of vitamin $C$ and serves as anti-inflammation, antibacterial and antibiotic. Flavonoid such as quercetin and epicatechin have antidiarrheal effect and can improve natural body immune response (Taylor and Towers, 1998). Saponin for non-ruminant feed (monogastric) like broiler is known to improve growth, feed efficiency and meat quality. Tannin derived from several plant extracts can prevent colonization of parasites, bacteria, protozoa and viruses in digestive tracts; therefore it is a common traditional medicine for diarrhea and dysentery (Maertens and Štruklec, 2006). Tugiyanti et al. (2016) reported that supplemental soursop leaves meals up to $15 \%$ has not lowered triglyceride, cholesterol, LDL and cholesterol levels in 10week male Tegal duck meat. Accordingly, the present study investigated the effect of supplementing soursop leaves meal on diameter of muscle fiber, lipid cell, growth and carcass percentage of Tegal duck.

\section{Materials and method}

The study was conducted in Sokaraja Kulon village in a $5 \times 15 \mathrm{~m}^{2}$ trial open cage with roof tile consisted of 30 experiment units measuring $1 \times 1 \mathrm{~m}^{2}$ that were equipped with fan, thermometer and humidity gauges with litter cage floor. Each unit had 5 ducks with a trough and a drinking container. Litter was replaced when wet or clumping.

Four-week male Tegal ducks weighing 1058.53 $\pm 38.08 \mathrm{~g}$ from Duck Farmer Group "Bebek Kumbaran", Negar Ayu village, Tonjong, Brebes is one native Indonesian breed used in the study, particularly those that hatched at the same time. The ducks were weighed to ensure the uniformity of body weight, then fed two times a day with water provided ad libitum. For one week prior to treatments, ducks were given preliminary feed that contained $21 \%$ protein and $3100 \mathrm{kcal} / \mathrm{kg}$ metabolic energy, then treatment feed was provided for 5 weeks. Feed intake was observed daily by calculating the amount of feed given minus feed leftover. Weekly body weight gain was measured to record, carcass percentage, diameter of muscle fiber and lipid level on breast meat was evaluated.

Measuring the diameter of breast muscle and the thickness of lipid cell was conducted using Scanning Electron Microscopic (SEM) tools (JEOL JSM 5000 LV Scanning Microscope). For preparation, sample was freezer-dried to obtain 
$2 \%$ or less water and cut $0.5 \mathrm{~cm} \times 0.5 \mathrm{~cm}$. The sample was then put on carbon-layered metal for gold coating ( $\mathrm{Au}$ ) $300 \AA$ inside Magnetron Sputtering Device equipped with vacuum pump. During the vacuum, the sample was sputtered with gold metal, put inside vacuum chamber in electron microscope and the light beams passed through it to produce an image. The length of fiber was measured using a method by Zingg (1935) where length represents the longest fuse, width is the medium fuse and thickness/height is the shortest fuse. Diameter formula was in accordance with Huebscher as follows:

$$
\text { de }=1.30 \times((a \times b) 0.625 /(a+b) 0.25)
$$

de $=$ equivalent diameter $(\mu \mathrm{m})$

$a=$ length of major side $(\mu \mathrm{m})$

$\mathrm{b}=$ length of minor side $(\mu \mathrm{m})$

Thickness of lipid cell was obtained by measuring the mean of width of lipid cells in several places.

Experimental research used completely randomized design utilizing four treatments; feed without soursop leaves meal supplement, feed plus 5, 10 and 15\% soursop leaves meal, each with 5 replicates to 5 ducks, producing 100 ducks in total. Diameter of breast muscle fiber, thickness of breast meat fat, body weight gain and carcass percentage of male Tegal duck were observed. The obtained data were subject to analysis of variance, followed by orthogonal polynomial test in case of significant effect (Steel and Torrie, 1997).

\section{Results and Discussion}

\section{Diameter of muscle fiber and thickness of breast lipid cell}

The shape of breast muscle fiber of male Tegal duck that were fed with soursop leaves meal was hexagon with core on the inside and endomysium tissue on the outside, while several other muscle fibers would form fasciculi. Microscope observation with 40X magnification showed that the size of muscle fiber in each treatment had relatively similar fiber magnitude and lipid that separated the fibers as presented in Figure 1.

Diameter of breast muscle fiber of male Tegal duck fed with soursop leaves meal supplemented in the feed is shown in Table 1.

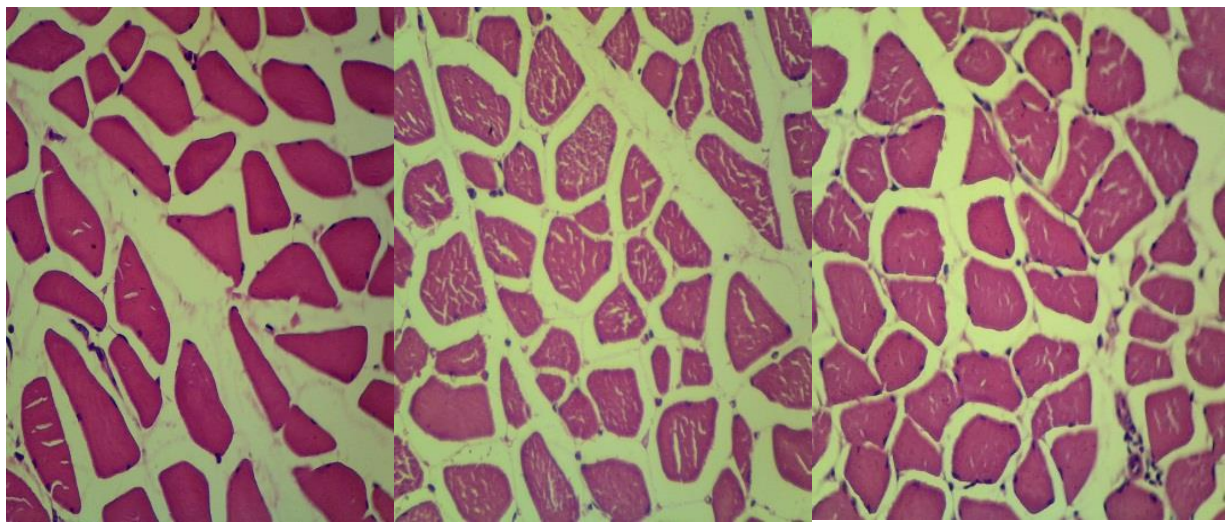

0\% Soursop leaves meal
$5 \%$ Soursop leaves meal

$10 \%$ Soursop leaves meal

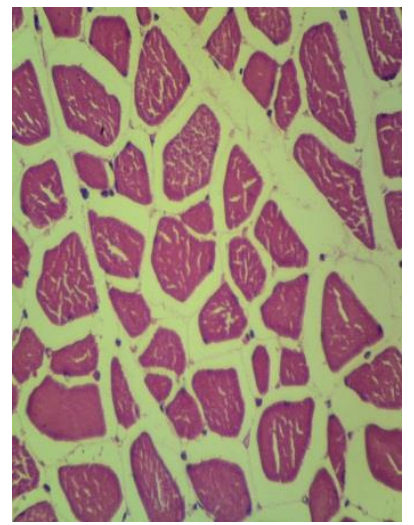

$15 \%$ Soursop leaves meal

Figure 1. Muscle fiberandfat cells of male Tegal duck 
The diameter of muscle fiber in this study was bigger than $15.24 \pm 2.99 \mu \mathrm{m}$ of 10 -week Mandalung duck (Sari, 2003). Soursop leaves meal supplement statistically increased diameter of breast muscle fiber of male Tegal duck, but analysis of variance showed the opposite result. It may due to the active substance in soursop leaves meal that act as antioxidant to prevent lipid auto-oxidation in duck's body.

Moreover, basal feed and daily feed intake was not significantly different across treatments. Choi and Kim (2008) stated that the increasing size of muscle fiber was contributed to protein and energy intake. The newly hatched poultry which lacks nutrients or obtains limited feed will have small muscle fibers and few fascicles (Rehfeldt et al., 2004).

Fast-growing poultry have bigger muscle fiber diameter and higher body weight gain due to the increasing size of muscle fiber 3 to 4 fold (Dransfield and Sosnicki, 1999). Poultry development through hyperplasia (multiplication of muscle fibers) may have been completed at hatching, so post-natal growth is contributed hypertrophic muscle fiber which occurs upon the interaction between satellite cells and muscle fiber and the factors of protein synthesis (Sosnicki and Wilson, 1991).

Lipid cells are commonly found under the skin (subcutaneous), among muscles, surrounding kidneys and heart, behind the eyeballs, bone marrow and stomach membrane. The measured lipid cells were located between muscle fiber of male Tegal duck meat. Lipid cell thickness of male Tegal duck breast meat that obtained soursop leaves meal supplement is presented in Table 1.

Supplemental of soursop leaves meal statistically lowered the lipid cell thickness, but analysis of variance showed that the supplementation non significantly affected lipid cell thickness of male Tegal duckbreast meat. It was because the polyphenol, flavonoid and other active substances in the soursop leaves mealcould not optimally increase the secretion of bile acid in feces.

Soeparno (2005) stated that cattle with balance nutrition diet subcutaneous, intermuscular and intramuscular lipid. Intramuscular fat is the last to develop in the lipid cells related to perimysium connective tissue. Therefore, lipid cell thickness is inseparable from diameter of muscle fiber because the inclusion of lipid cells into muscle connective tissue can increase muscle diameter size. Fat deposit unloading started from adipose cells or fat tissues such as visceral and subcutaneous, after which in muscle tissue (Fauziyati, 2008).

\section{Body weight gain}

Analysis of variance on body weight gain showed that supplementation of soursop leaves meal in feed significantly affected $(P<0.05)$ body weight gain of male Tegal duck. In this case, the higher supplement level, the lower body weight gain. The average decline of body weight may due to the decreasing feed intake.

Table 1. Diameter of muscle fiberandthickness of breast lipid cellof ducks in each treatment

\begin{tabular}{|c|c|c|c|c|}
\hline \multicolumn{5}{|c|}{ Treatments } \\
\hline & SO & S1 & S2 & S3 \\
\hline $\begin{array}{l}\text { Diameter of breast } \\
\text { muscle fiber }(\mu \mathrm{m})\end{array}$ & $20.84 \pm 3.51$ & $22.35 \pm 2.74$ & $23.83 \pm 3.32$ & $22.00 \pm 1.51$ \\
\hline $\begin{array}{l}\text { Breast fat cells } \\
\text { thickness }(\mu \mathrm{m})\end{array}$ & $20.41 \pm 3.79$ & $17.87 \pm 0.88$ & $17.79 \pm 4.73$ & $15.62 \pm 4.66$ \\
\hline
\end{tabular}


Soursop leaves meal, according to Harborne (1988) contains Annonain, an alkaloid compound which turns bitter and toxic when the amount is excessive.

Furthermore, soursop leaves meal also contains saponin that may decrease protease activity in digestive tract and distract feed adsorption. Nursal (2003) highlighted that low feed intake accompanied by alkaloid content in feed will inhibit growth rate because the energy destined for growth rate is used for neutralizing toxic instead, therefore the growth rate suffers.

Result of orthogonal polynominal test showed that supplementation of soursop leaves meal resulted in quadratic response $(P<0.05)$ to body weight gain of 9-week male Tegal duck with equation $Y=427.74-67.10 X+2.27 X^{2}$ and coefficient determination (R2) 92.94\%, indicating that body weight gain was affected by the supplementation level of soursop leaves meal (Annona muricata L.) (Figure 2). The peak point in the graph $(X=15 \%$ and $Y=-81.30 \mathrm{~g})$ indicated that $15 \%$ soursop leaves meal (Annona muricata L.) lowered body weight of male Tegal duck.

\section{Carcass percentage and carcass components}

Carcass components are muscle, fat, skin and bone with different growth rate. Among the four components, bone has relatively lower growth coefficient, while the other three have relatively bigger growth coefficient on slaughter weight (Anggraeni, 1999).

Analysis of variance showed that supplementation of soursop leaves meal did not significantly affect $(P>0.05)$ carcass percentage. Crude fiber in soursop leaves can inhibit ducks' growth including carcass growth. The result indicated that carcass percentage of ducks in 5 and $15 \%$ treatments was higher but not significant than that of $0 \%$.

Subhan et al. (2009) stated that carcass weight is related to the live slaughter weight. Kleczek et al. (2006) mentioned that body weight and body weight gain of water poultry are good indicator of carcass percentage and carcass composition, indicated by positive correlation (r) $0.30-0.65$. It was in accordance with Hudallah et al. (2007) that one of the contributing factors to carcass weight was slaughter weight. Therefore, the higher the slaughter weight, the higher carcass weight (Rukmiasih, 2011).

Result proved that body weight gains of ducks that received $0,5,10$ and $15 \%$ supplementation declined, so the carcass percentage was reduced as well, except for the $10 \%$ group that had higher percentage than the 5 and 15\%. Omojola (2007) reported that the contributing factors to carcass percentage of Pekin duck are sex, farming management, breed and body weight.

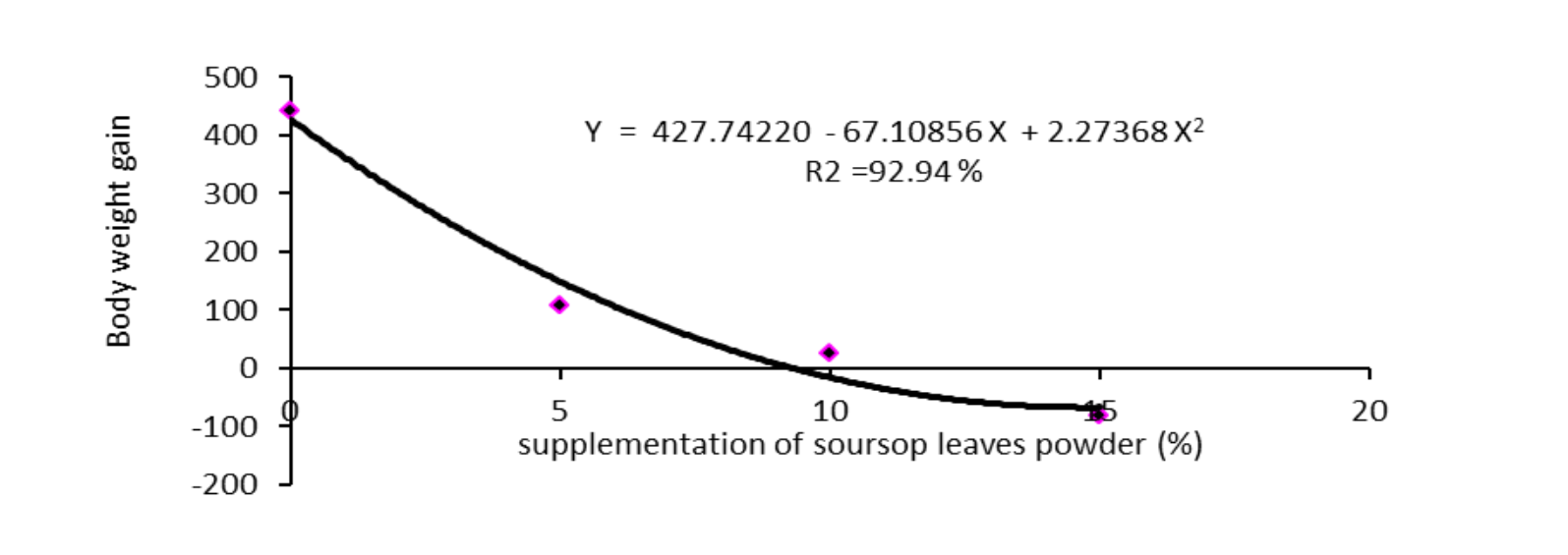

Figure 2. Supplementation of soursop leaves meal (Annona muricata L.) on body weight gainof Male Tegal duck. 
Table 2. Body Weight Gain, Carcass Percentage, and Carcass components of Male Tegal Duckin Each Treatment.

\begin{tabular}{lcccc}
\hline \multicolumn{5}{c}{ Treatments } \\
\hline Body weight gain (g) & $441.73 \pm 52.81^{\mathrm{a}}$ & $107.06 \pm 63.75^{\mathrm{b}}$ & $26.00 \pm 24.79^{\mathrm{b}}$ & $-81.30 \pm 42.38^{\mathrm{c}}$ \\
Karkas Total (\%) & $51.59 \pm 4.71$ & $49.04 \pm 2.30$ & $51.71 \pm 5.14$ & $47.95 \pm 4.866$ \\
Dada (\%) & $14.65 \pm 2.59$ & $13.60 \pm 2.32$ & $13.91 \pm 1.39$ & $13.22 \pm 2.157$ \\
Sayap (\%) & $9.22 \pm 1.05$ & $9.45 \pm 0.59$ & $10.04 \pm 1.07$ & $9.94 \pm 1.421$ \\
Paha (\%) & $12.66 \pm 1.71$ & $11.25 \pm 2.21$ & $13.53 \pm 1.13$ & $11.68 \pm 1.509$ \\
Punggung (\%) & $15.06 \pm 4.97$ & $14.73 \pm 2.27$ & $14.22 \pm 3.15$ & $13.10 \pm 3.994$ \\
\hline
\end{tabular}

S0: basal feed/control, S1: basal feed $+5 \%$ soursop leaves powder, $S 2$ : basal feed $+10 \%$ soursop leaves powder), S3: basal feed $+15 \%$ soursop leaves powder).

$a, b, c$ different superscripts within row indicate significant differences $(P<0.05))$.

Growth, body composition, carcass and carcass components may differ among duck breeds as the specific characteristics. Breast percentage in treatment $0 \%$ was higher than that of 5, 10 and $15 \%$ due to crude fiber content in soursop leaves that affect meat growth. Breast carcass is dominated by meat, so carcass percentage of breast part kept declining as the level of soursop leaves meal was increased. However, the percentage yield was relatively similar, so the supplementation of soursop leaves meal did not significantly affect $(P>0.05)$ breast carcass percentage. Armissaputri (2013) reported that the percentage of breast carcass of 10 -week Tegal duck was $13.95 \%$, relatively similar to $13.84 \%$ in the present research.

Percentage of duck' wings with soursop leaves meal supplement were higher than that without supplement due to different final body weight. However, analysis of variance showed that soursop leaves meal supplement did not significantly affect $(P>0.05)$ wing percentage since the percentage yield was relatively similar. Averaged carcass percentage on wings in this research was $9.66 \%$ while Purba and Prasetyo (2014) reported $11.05 \%$ on 12 -week Tegal duck.

Leg carcass percentage of treatment 10 and $15 \%$ was lower than that of $0 \%$. Analysis of variance showed that supplementation of soursop leaves meal did not significantly affect ( $P>0.05$ ) leg percentage of male Tegal duck as shown from the relatively similar leg percentage before and after treatment.
However, Purba and Prasetyo (2014) reported that high crude fiber in feed did not significantly affect $(P>0.05)$ the weight of duck leg. Similar result was obtained in ducks' proportional weight of back and wings meat. Mean leg carcass in the present study was $12.28 \%$, while Armissaputri (2013) reported $13.26 \%$ on 10 week Tegal duck.

There is only a little meat on the back part, even dominated with bone, and meat directly attached to columna vertebralis sternum and the other bone. Analysis of variance showed that supplementation of soursop leaves meal did not significantly affect back percentage ( $P>0.05)$. Bone is important to support body, growing rapidly in the early development then the growth rate is declining as it gets older. The back percentage of 4-10 week-Mandalung duck has negative allometric coefficient (Astuti, 2014). It showed that as the ducks get mature, the back percentage is not significantly increased or relatively similar. The back percentage of this research was $14.27 \%$, similar to $17.47 \%$ of 12 -week Tegal duck (Purba and Prasetyo, 2014) and $14.3 \pm 05 \%$ and $14.7 \pm 0,4 \%$ of male and female Gemba duck, respectively (Matitaputty and Bansi, 2016).

\section{Conclusions}

Supplementation of soursop leaves meal (Annona muricata L.) in feed has not been able to increase the muscle fiber diameter of 
intermuscular lipid cell, carcass percentage and carcass components. Excessive supplement even lowers the body weight gain of male Tegal duck.

\section{References}

Anggraeni. 1999. Allometric growth and morphology review of Tinjauan Morfologi Breast muscle fiber (Muscullus pectoralis and Muscullus supracoracoracorideus) of native Muscovy and mallard. Dissertation. Graduate school of Bogor Agriculture Institute. Bogor.

Armissaputri NK, Ismoyowati and S Mugiyono. 2013. Different weight and percentage of carcass and non-carcass components of native Muscovy (Anas plathyrincos) and mallard (Cairina moschata). Jurnal Ilmiah Peternakan. 1(3):10861094.

Astuti IP. 2014. Carcass and non-carcass percentageof crossbredMandalung duck and Cihateup duck at different ages. Undergraduate thesis. Faculty of animal science IPB. Bogor

Chikmawati T and Miftahudin. 2011. Diversity of Selaginella from Java Island. National Seminar, Congress and Simposium of Indonesian Society for Plant Taxonomy IX. Kebun Raya Eka Karya, Bali 11-13 Oktober.

Choi YM and BC Kim. 2008. Muscle fibre characteristics, myofibrillar protein isoforms, and meat quality. Livest. Sci.: 1-14.

Dransfield, E and AA Sosnicki. 1999. Relationship between muscle growth and poultry meat quality. Poult Sci. 78(5):743-746.

Fauziyati, A. 2008. Physiological adaptation during fasting. Jurnal Penelitian and Pengabdian. 5:1-9.

Harborne, JB. 1988. Introduction To Ecological Biochemestry. 3th Edition. Academic Press, London.

Hudallah, CM, S Lestari and E Purbowati. 2007. Carcass and non-carcass percentageof male native lamb under different feeding method. National Seminar Animal Husbandry and Veterinary. Faculty of Animal Science, Diponegoro University. Semarang.

Jun, K, OH Rock and OM Jin. 1996. Chemical composition of special poultry meat. Chungnam Taehakkyo. 23(1):90-98.

Kim, GD, JY Jeong, SH Moon, YH Hwang, GB Park and ST Joo. 2006. Effects of Muscle Fibre Type on Meat Characteristics of Chicken And Duck Breast Muscle. Division of Applied Life Science, Graduate School, Gyeongsang National University, Jinju, Korea. Gyeongnam:660-701.
Kleczek, K, K Wawro, E Wilkiewicz-Wawro and W Makowski. 2006. Multiple Regression Equations To Estimate The Content Of Breast Muscles, Meat, And Fat In Muscovy Ducks, Production, Modeling and Education. Poult. Sci. 85:13181326

Maertens L and Štruklec M. 2006. Technical note: Preliminary results with a tannin extract on the performance and mortality of growing rabbits in an enteropathy infected environment. World Rabbit Sci. 14:189-192.

Matitaputty PR and H Bansi. 2016. Growth and carcass production of native Gemba duck at 12 weeks old.National Animal Husbandry Seminar 2, Faculty of Animal Science, University of Hasanuddin Makassar, tanggal 25 Agustus 2016.

Nursal, NP. 2003. Nutrition Index of Larva Instar V Heliothis Armigera Hubner on food that contain mangrove bark extract (Rhizophora Mucronata Lamk.) at different temperature. Undergraduate thesis. FMIPA USU.

Omojola, AB. 2007. Carcass and organoleptic characteristics of duck meat as influenced by breed and sex. Int. J. Poult. Sci. 6(5):329-334

Purba, M and LH Prasetyo. 2014. Growth response and carcass production of EPMp ducks on different content of crude fiber and protein in feed. JITV. 19(3):220-230

Prasetyo, E Mukson, BM Setiawan and W Sumekar. 2004. Development profile of agribusiness area in Central Java Province. Research Report. Faculty of Animal Science, Diponegoro University. Semarang.

Rehfeldt, C, I Fiedler and NC Stickland. 2004. Number and Size of Muscle Fibres in Relation to Meat Production. In: Muscle Development of Livestock Animals, Physiology, Genetics and Meat Quality. Edited By M.F.W. te Pas, M.E. Everts and H.P. Haagsman eds. CABI Publishing. London,UK.

Rukmiasih, PS Hardjosworo, PP Ketaren and PR Matitaputty. 2011. Penggunaan Beluntas, Vitamin C and $\mathrm{E}$ sebagai Antioksidan untuk Menurunkan Off-Odor Daging Itik Alabio and Cihateup. JITV. 16(1):9-16.

Sari, ML. 2003. Allometric growth of Mandalung duck and histological review on legmuscle fiber paha. In: Proceedings of National Seminar Animal Husbandry and Veterinary. Bogor, 29-30 September 2003. ICARD. Badan Litbang Pertanian. Pp:496-500.

Soeparno. 2005. Meat science and Technology. $3^{\text {rd }}$ Ed. Gadjah Mada University Press. Yogyakarta. Pp:637.

Sosnicki AA and BW Wilson. 1991. Pathology of turkey skeletal muscle: Implications forthe poultry industry. Food Struct. 10:317-326. 
Srigandono, B. 1997. Ducks Farming. Gajah Mada University Press, Yogyakarta.

Steel, RGD and JH Torrie. 1993. Principal and procedure of statistics. Translated by B Sumantri. PT. Gramedia. Jakarta. Pp:748.

Subhan, A, ES Rohaeni and R Qomariah. . 2009. Effect of combined steamed sago and golden snail meal in formula feed on performance of 1-8 weeks male MA duck. In: Proceedings of National Seminar of Animal technology and Veterinary. ICARD. Bogor.

Sudiyono and Purwatri. 2007. Effect of additional enzyme in ration on carcass percentage and carcass components of male native duck. Jurnal Pengembangan Peternakan Tropis. 32:270-277.
Susanti T and Prasetyo LH. 2007. Guide to characterization of duck farming. Bogor (Indonesia): ICARD.

Suranto, A. 2011. The power of soursop against disease. Pustaka Bunda, Jakarta.

Taylor, RSL and GHN Towers. 1998. Antibacterial constituents of the Nepalese herb, Centipeda minima. Phytochemistry. 47:631-634.

Tugiyanti, E, S Heriyanto and AN Syamsi. 2016. Effect ofSoursop leaves meal (Announa Muricata L.) on Characteristics of blood lipid and meat fat of Male Tegal duck. Buletin Peternakan. 40(3):211218. 